\title{
Analysis of Factors that Gives the Influence on Profitability of TunaCapture Fisheriesfishermen Household in Maluku Province
}

\author{
Steven Siaila \\ Economy Faculty, University of Pattimura, Ambon Indonesia
}

\begin{abstract}
This study aims to analyze the activity of tuna catching investigated based on profitability level. Variables analyzed were investment, experience and operational cost on operational frequency, catching productivity and operationalrevenueas well as provitability.Data were analyzed by usingStructural Equation Model (SEM) formulation to determine the effect between exogen and endogen variable. The research population was all households of tuna capture fisheries fishermen in Maluku Province. Sample collection technique was by using Area Sampling Method combined with Purposive Sampling Method. Sample collected was 270 respondents from Ambon city, Maluku Tengah Regency, Buru Regency, and West Seram Regency.The results of study were: The first, there was the significant effect among investment, experience and operational cost on operational frequency, productivity, operational revenue and household profitability of tuna fishermen in Maluku Province. The second, household of tuna fishermen still has the potential to be developed by investment addition that can increase profitability. The third,operational cost addition directly increased operational revenue and profitability.
\end{abstract}

Keywords:Fishing effort, Profitability, Tuna, Maluku Province

\section{Introduction}

Maluku Province is consisted of 93,5\% ocean containing marine resource potency which interests to investor for exploiring of this potency. Based on fishing production level in Indonesia,Maluku Province has been in top position with the fishing of 481.848 ton, followed by North Sumatera and East Java with fishing of 326.336 and 322.292 ton, respectively[1]. Maluku Province is placed in 3 fisheries management area namely; Banda, Arafura and Seram Ocean to Tomini Bay commulatively and contains fish resource potency reach 1.640 ton/yearwith the use of $42 \%$ [1] This fact showed that East Indonesia Waters area still has the bigger potential than fishing volume achievement [2].Therefore, there is the oppurtinity to develop fisheries in East Indonesia Region $[3,4]$

Over-exploited fishing in West Indonesia Region caused East Indonesia Region to be fishing ground by ships which do fishing in this Region including Moluccas Province. This condition caused capture fishery companies particularly household industry of capture fisheryin Maluku Province must have faced with the biger ship fleet which has the modern fishing equipments. Due to this situation, company profitability became the most important factor to depend the continuity of capture fishery effort.

The activity success of fishing is often determined based on the defference of importance with various efficiency namely; businessmen efficiency and consumer efficiency. Businessmen effieciency is the achievement of profit to businessmen by comparison to the cost spending. Therefore, profitability as out-puhe bit of the economic activity in fishery subsector must be compared to the operational cost of fishing in the sea. Meanwhile, consumer efficiency is determined based on consumer satisfaction as an out-put compared to individue efforts to give the satisfaction [5].

In recent year, the use of fishery resource particularly capture fisheryhas been dominated by populace fishery industry which commonly has characteristics: small industry scale,simple technology application, catching operation limited around coastal, and low relative productivity $[6,7]$

The low fishermen productivity was commonly caused by the low skill and knowledge.It was also due to the use of simple catching equipment and ship being effectivity and efficiency of catching equipment as well as the use of unoptimal other production factors. These factors very influence on fishermen income and finally give the effect on their prosperity level.

Hilborn and Walters(1992)reported that the activity of fishermen economy to respond government wisdom and non wisdom is always linked to environment dynamics and fishing fleet dynamics in the effort of simultaneous fish resource exploitation.Fishery system has a very complex interaction among fish stock dynamics, fishing fleet and production factors such as fund and workers of fishermen household in exploitation of fish stock[8].

To understand economics dynamics and fishery management, it is need study by system approach which considers fish resource stock and fishing fleet dynamics to guarantee the availability of work field and the increasing of fishermen income. Finally, these guarantees will determine the achievement of company 
profitability. If the activity of fishing is not purposed on the achievement of company profitability, the fishing effort continuity will face to unclear effort activity[9]

\section{Literature Study}

Profitability well known as Net Profit Margin in capture fishery companiesis the ability reflection of every rupiah of catching value in the particular period to result in profit after being subtracted with interestand tax.Return On Assets Ratio (ROA) is used to determine company profitability [10].

Profitability of tuna capture fishery company based on fishery production concept is very depended on capital expenditures and revenue expenditures. Capital expenditures are investment on the main equipment of tonda fishing activity. Meanwhile, revenue expenditures are the activity expense to go to sea[11].

Activity of capture fishery company operationalmust be able to reach profitable level in orther to operational cost management as the main cost of company operational activity must be well managed to prevent a waste of cost in operational activity and reach wanted operational efficiency level [12,13].

Based on the explanation above, it can be formed a conception design replecting the relationship and effect among variables as followed:

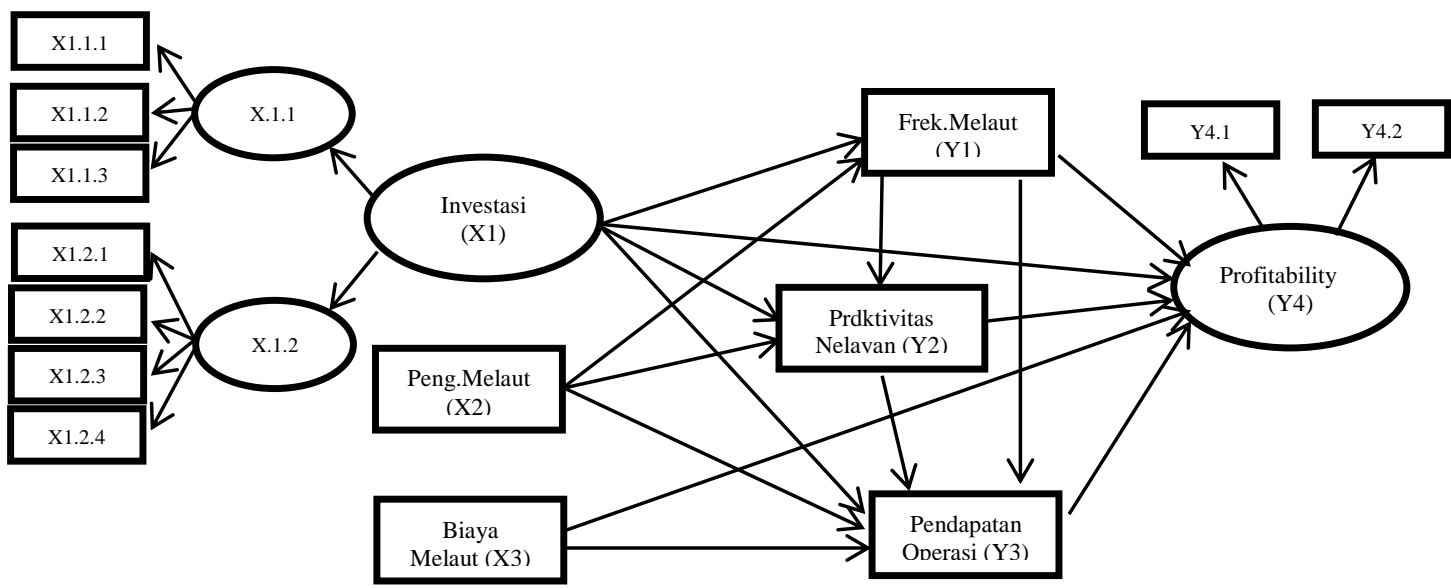

Figure. 1. Structural Relationship of X1, X2,X3, Y, Y2, Y3 and Y4 Variables

Keterangan:

$\mathrm{X}_{1} \quad=$ investment,

$\mathrm{X}_{1.1} \quad=$ The main equipment of tonda fishing,

$\mathrm{X}_{1.1 .1} \quad=$ Casco,

$\mathrm{X}_{1.1 .2}=$ Outboard engine,

$\mathrm{X}_{1.1 .3}=$ Fishing equipment,

$\mathrm{X}_{1.1 .4}=$ the other equipments,

$\mathrm{X}_{1.2}=$ tonda fishing assistant equipment,

$\mathrm{X}_{1.2 .1}=$ Cool boxes,

$\mathrm{X}_{1.2 .2}=$ Spear,

$\mathrm{X}_{1.2 .3}=$ Ganco,

$\mathrm{X}_{1.2 .4}=$ Oar,

$\mathrm{X}_{1.2 .5} \quad=$ The other assistant equipments,

$\mathrm{Y}_{4.1}=$ Net Proft Margin,

$\mathrm{Y}_{4.2} \quad=$ Return On Asset

Direct effect estimation process and indirect effect of analyzed variables estimated to give the effect on profitability of tunacapture fishery fishermen household in Moluccas Province was started by formulation of analysis variable function as followed:
1. $\mathrm{Y}_{1}=\mathrm{f}\left(\mathrm{X}_{1}, \mathrm{X}_{2}, \mathrm{X}_{3}\right)$
2. $Y_{2}=f\left(X_{1}, X_{2}, X_{3}, Y_{1}\right)$
3. $Y_{3}=f\left(X_{1}, X_{2}, X_{3}, Y_{1}, Y_{2}\right)$
4. $Y_{4}=f\left(X_{1}, X_{2}, X_{3}, Y_{1}, Y_{2}, Y_{3}\right)$

This study aims to determine and analize: (1) investment effect, experience and cost to go to sea,(2) investment effect, experience and operational cost on production, (3) Effect of operational frequency on production, (4) investment effect, experience and operational cost on operation revenue, (5) Effect of 
operational frequency and production on operational revenue, and (6) Effect of operational frequency, production and operational revenue on profitability.

\subsection{Research Kind}

\section{Methods}

This study was explanatory research with house hold of capture fishery company doing tuna fishing in fisheries management region around Banda and Seram Ocean to Tomini Bay as the analysis unit.

\subsection{Data Kind}

Data used was primary and secondary data. Primary data collection was carried out by using questionnaire and interview. Mean while, secondary data was collected from Fisheries Service and other download data supporting this research

\subsection{Data Collection}

Data collection method used was Probability Sampling Method. Based on this method, it was carried out data collection by combination of Area Sampling Method and Purposive Sampling method[14].

\subsection{Data Analysis}

Data analysis method used was Structural Equation Modeling(SEM) to determine the relationship among causal variables in structural equation [15]. These variable wereInvestment (Capital expenditures) $\left(\mathrm{X}_{1}\right)$, Operational Cost $\left(\mathrm{X}_{2}\right)$,Operational Frequency $\left(\mathrm{Y}_{1}\right)$, Productivityor effective catchment level $\left(\mathrm{Y}_{2}\right)$, Company operational revenue $\left(\mathrm{Y}_{3}\right)$,Profitability of tunacapture fishery fishermen household $\left(\mathrm{Y}_{4}\right)$.

Weekly effective catch level was determined by equation as followed:

Productivity /trip $(\mathrm{kg} /$ trip $)=\frac{\text { Production number }}{\text { Fishing trip number }}$

Profitability indicator of tuna capture fishery fishermen household is:

a. Net Profit Margin atau NPM $\left(\mathrm{Y}_{4.1}\right)$ is determined by equation as followed:

$$
\mathrm{NPM}=\frac{\text { Net profit }}{\text { Selling }} \times 100 \%
$$

b. Return On Assets atau ROA $\left(\mathrm{Y}_{4.2}\right)$ is determined by equation as followed:

$$
\text { ROA }=\frac{\text { Net profit }}{\text { Assets }}
$$

\section{Results}

\subsection{Description of Tuna Capture Fishery Fishermen Household in Maluku Province}

\subsubsection{Tuna Capture Fishery Fishermen Household Profile}

Tuna capture fishery fishermen household isautonomous individue industry form managed by husband and wife as the owner assisted by children and closed family in which its industry activity is fishing. Commonly, these industries use their own money to supply fishing operational tool. Every fishermen household industry must register to its state facility fito establish fisheries fishermen household industry proved by Decision Letter of Fisheries and Marine Service.

Since the beginning of 2010, tuna capture fishery fishermen household in Maluku Province has become a part of Rural Mina Business Program which is be operational program of Marine and Fishery Society.

\subsubsection{Decription of TunaCapture Fishery Fishermen HouseholdOperational Activity}

Operational activity of tunacapture fishery fishermen household was done by two people consisted of business owner and one family member. The operational activity was done in 2 fishing ground area namely; around Buru Island Waters at East season and moved to Banda Ocean at West season. Tools used were ship/casco, outboard enginehaving a capacity of $15 \mathrm{PK}$ or $25 \mathrm{PK}$, fishing tool, and the other operational assistanttools. 
Operational time pertrip of every region was different each other. Fishermen in area Ambon city, West Seram Regency and Central Maluku Regency Regions need 12 hours operational time (from 05.00 to 17.00) whilst, Banda Subdistrict and Buru Regency need 7 ( 09.00-17.00) and5 hours (07.30-14.00), respectively. This operational time difference was caused by each Regency/City geographical location. Compared to Buru Regency and BandaSubdistrict, Ambon City, East Seram Regency and Central Maluku had a far distance fromhome-base to fishing ground.

Based on the skill belonged to fishermen of tuna capturefishery fisherman household, almost all respondent had never attended workshop of fishing and business management. It was due to this kind of workshop had never been done by technical service.

\subsubsection{Respondent Character}

Respondents of tuna capture fishery fishermen household were dominated by respondents withthe age $30-40$ years $(49.3 \%), 41-50$ years(36.7 \%), and above50 years $(1.9 \%)$. It showed that productive age is dominant age of respondents. It has the relationship to faced challenge when they do fishing in which they need a strong stamina.

Based on education background, almost a half of respondets (45.2\%) or 122 respondents only graduation of elementary school.There were only 17 respondents $(26.3 \%)$ and $28.5 \%$ respondents graduate of yunior and senior high school, respectively. It means respondents dominated by respondent education level of elementary school.

\subsection{Research Variable Descriptive Analysis}

\subsubsection{Investment}

Capital Expendituresor $\mathrm{X}_{1}$ iscost spended to supply tools of fishing operational consisted of:

a. Ship as the main operational tool of tuna capture fishery fishermen household was made of fiber-glass with 2 different size each namely; (1) $7 \mathrm{~m}$ length, 1 wideand $70 \mathrm{~cm}$ height; (2) $9 \mathrm{~m}$ length, $1.5 \mathrm{~m}$ wideand $1 \mathrm{~m}$ height.

b. 198 ships were supplied in 2001 to 2004 whilst, 72 ships were bought in 2005 to 2009.It means the big operational activity of tuna capture fishery fishermen household started from 2001 to 2006 proved by the increasing of tuna capture fishery fishermen household supported by ship number increasing.

Cost need for ship supplying was range Rp. 2000000,-to Rp. 5000000,-. Ship used for fishing operational had the small relative size. Due to this small size, ship flexibility in doing fishing activity was very high. Outboard engineused had a capacity of 15 PK and 25 PK. In 2001, the price of outboard enginewith the capacity of 15 PK was Rp. 9.500.000,-and continued to increase until Rp.15000000ino 2009. Meanwhile, the price of outboard engine with the capacity of 25 PK wasRp. 17000000,-in 2001 and continued to increase 22acilRp. 23000000,- in 2008.

c. Capture tools were consisted of nylonand fishingtackle. A unit of these tools had the price of Rp. 200000,22acil Rp. 350000,- with nylon and fishing tackle reserve per unit which had the price of Rp. 45000,- 22acil Rp. 90000,- . Cost average need to supply these capture tools and their reservewas Rp. 304908,-and Rp. $67225,-$, respectively.

d. Two units of cool boxes, spear, ganco and oar1 unit each and other tools such as various size of rope, knife and kite. The mostcool boxes used by tuna capture fishery fishermen household were cool boxes with the size of 1-1.5 m length. For cool boxes were need the cost average of Rp.248257,- .

The whole cost average used for tuna capture fishery operational activity was Rp. 19.460.880,-

\subsubsection{Fishing Operational Experience}

Fishing operational experience is variable chosen as a proxy for fishing operational skill. From the whole sample, fishing operational experience of tuna capture fishery fishermen household is divided by 2 groups namely; the age of 0-5 yearsand more than 6 years. From 270 samples, 207 tuna capture fishery fishermen house hold had fishing experience more than 6 yearswhilst, 63 of them had fishing experience less than 6 years. Overall, tuna capture fishery fishermen house hold experience average was 7 years. It indicated that tuna capture fishery fishermen householdhad more experience in fishing. Therefore, they could be estimated to have more skill in fishing and managed fish pasca capture in time of $\geq 1$ hour.

\subsubsection{Operational Cost}

Fishing operational cost is cost need to operate fishing activity in the sea consisted of variable cost such as fuel, oil, ice, ration, and other costs.

The whole fishing operational cost is variable cost element and cost of the whole sample was Rp. 405351,-. Based on the high cost variable, fuel and oil cost werecost element dominating the high variable cost of $71.25 \%$ and the rest of $28.75 \%$ for other elements. 
Permanent cost counted for one fishing operational trip is the cost spended to operateship and outboard engine as well as tuna fishing activity. Cost average spended for shrinkage of ship and outboard engine was Rp. 47.034 per/week whilst, their treatment cost was Rp. 125468,- Fee averagefor 2 fishermen of tuna capture fishery fishermen household was Rp. 105. 026,-/tripFrom these expenditure samples, It could be concluded that in general, the cost spended for fishing operational activity was Rp. 277. 528,-/trip.

\subsubsection{Fishing Operational Frequence}

From this study, there was obtained thatfishing operational frequence of tuna capture fishery fishermen household range from 3 to 6 times a week.Overall, fishing operational activity average of respondents was 5 times a week. If it was occurred the low fishing operational frequence, it was due to the lack of fund for fuel, oil, ice as the main need.

\subsubsection{Produktivity or Effective Catch Level}

Produktivity or effective catch level is reflection of tuna capture fishery fishermen household ability in getting of fish catch in one period. Ambon city produced $69 \mathrm{~kg}$ fish in a week whilst, Fish production of Central Moluccas, West Seram and Buru Regency were 56, 56and $63 \mathrm{~kg}$ fish a week, respectively.From their fish production determined by effective catch level, Ambon city had the highest fish production followed by Buru and Central Moluccas and West Seram Regency.

\subsubsection{Fishing operational revenue}

Fishing operational revenue is income counted based on the comparison of fish catch number per week to the sale price of tuna.

Fishing operational revenue average of samples collected was Rp. 2201154,- in which tuna capture fishery fishermen household located in Ambon was obtained to give the highest operational revenue ( $R p$. 3655000,-).It was due to Ambon more productive than the other cities besides the fish sale price was Rp. 42500,-to Rp. 45000,- higher than the fish sale price in Banda Neira subdistrict (Rp. 13500,- to Rp. 20000,-).

Related to the operational revenue at impassable dot of Rp. 341362.62,-,the operational revenue of tuna capture fishery fishermen household per trip was higher. This value was much higher than the main cash back dot.

\subsubsection{Profitability of Capture Fishery Household Business}

Profitability analysis of capture fishery household in Moluccas Province is purposed on the ability for resulting profit by comparing net profit with production assets use.

Commonly, net profit margin of tuna capture fishery fishermen household respondents is $47.80 \%$ of 50.00-59.99 \% level, $46.7 \%$ of 40.00-49.99 \% level and 5,60 \% respondents of 30.00-39.99\% level. The high net profit margin proved that the good ability of tuna capture fishery fishermen household to yield the high profit with net profit margin of $>40.00 \%$ which means this business is profitable.

The high Return On Assets (ROA)indicated that the very high ability average of tuna capture fishery fishermen household to yield profit by using their assets was more than $30.00 \%-99.99 \%$. At the ROA value > $40.00 \%$, the profit number resulted was higher than ROA level target (30.00\%-39.99\%). It showed that tuna capture fishery fishermen household business has the potential to be developed.

\subsection{Investment Functional, Fishing Operational Experience, Operational Cost, Operational Frequency, Productivity, Operational Revenue, and Profitability Relationship}

Analisis Structural Equaion Model Results by using data collected from this study were summarized in Table below.

Table 1. Analisis Structural Equaion Model Results by using data collected from this study

\begin{tabular}{|c|c|c|c|c|c|}
\hline & Estimation & S.E. & C.R. & $\mathrm{P}$ & Lable \\
\hline $\mathrm{Y} 1 \leftarrow-\mathrm{X} 1$ & .109 & .020 & 5.405 & $* * *$ & Significant \\
\hline $\mathrm{Y} 1 \leftarrow-\mathrm{X} 2$ & .381 & .006 & 62.165 & $* * *$ & Significant \\
\hline $\mathrm{Y} 1 \leftarrow-\mathrm{X} 3$ & .019 & .011 & 3.584 & $* * *$ & Significant \\
\hline $\mathrm{Y} 2 \leftarrow-\mathrm{X} 1$ & 1.526 & .403 & 3.788 & $* * *$ & Significant \\
\hline $\mathrm{Y} 2 \leftarrow-\mathrm{X} 1$ & 1.526 & .403 & 3.788 & $* * *$ & Significant \\
\hline $\mathrm{Y} 2 \leftarrow-\mathrm{X} 2$ & 5.228 & .551 & 9.485 & $* * *$ & Significant \\
\hline $\mathrm{Y} 2 \leftarrow-\mathrm{X} 3$ & .020 & .005 & 3.367 & $* * *$ & Significant \\
\hline $\begin{array}{lll}\mathrm{Y} 2 & \leftarrow- & \mathrm{Y} 1 \\
\end{array}$ & 12.627 & 1.424 & 8.866 & $* * *$ & Significant \\
\hline Y3 $\leftarrow-\quad \mathrm{X} 1$ & 1087743.924 & 88230.688 & 12.328 & $* * *$ & Significant \\
\hline
\end{tabular}




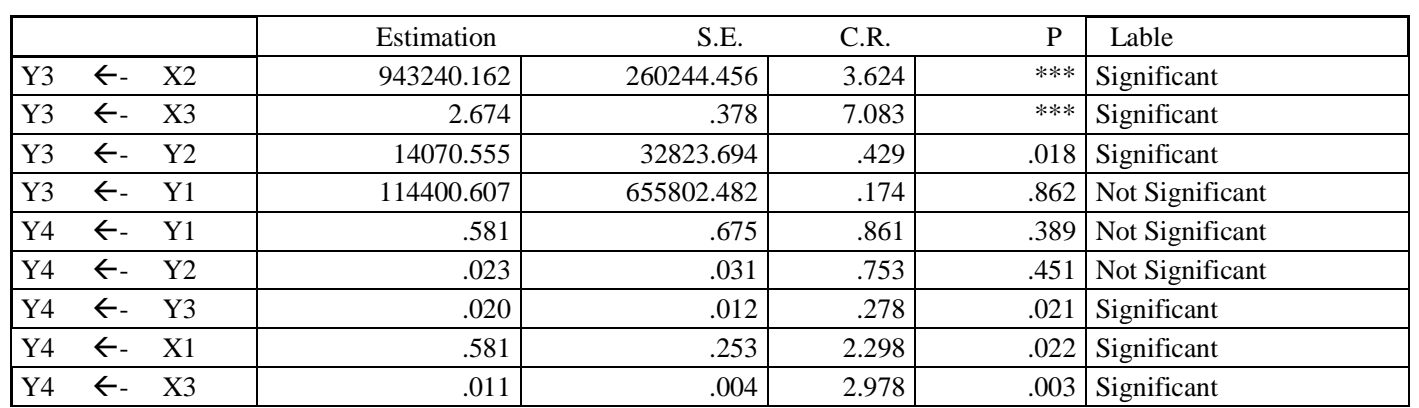

Suouce : Primary Data reanalyzed

\subsubsection{Direct Effect}

a. There is the positive and significant effect of fishing operational investment, experience, cost, and frequency

The first, direct effect analysis result of investment variable $\left(\mathrm{X}_{1}\right)$ on operational frequency variable $\left(\mathrm{Y}_{1}\right)$ determined through effect coefisient 0.109 with significant level of $0.000<0.05$ and its ratio critical value of 5.405. These values give the information that there is positive and significant direct effect betweeninvestment variable $\left(\mathrm{X}_{1}\right)$ with operational frequency variable $\left(\mathrm{Y}_{1}\right)$. It means if there is investment variable change $(\mathrm{X} 1)$ of 1 unit, it will be followed by operational frequence variable change $\left(\mathrm{Y}_{1}\right)$ of 0.11 with the similar purpose and the other factors value is constant.

The second, coefisient of operational experience variable effect $\left(\mathrm{X}_{2}\right)$ on operational frequence variable $\left(\mathrm{Y}_{1}\right)$ is 0.381 with significance level of $0.000<0.05$ and critical ratio of 62.165 . These values showed that there is positive and significant direct effect between operational experience variable (X1) and operational frequency $\left(\mathrm{Y}_{1}\right)$ namely; if individue experience of 1 member of tuna capture fishery fishermen householdincreases in 1 measurement unit, it will increase operational frequence of 0.31 times with other factors perception of constant. The more individue experience of 1 member of tuna capture fishery fishermen household, means the more opportunity of tuna capture fishery fishermen household to increase operational frequency.

The third, effect coefisient between operational cost $\left(\mathrm{X}_{3}\right)$ and operational frequency $\left(\mathrm{Y}_{1}\right)$ is 0.19 with critical ratio value of 3.584 and probability errorvalue of $0.000<0.05$. These values give the information that operational cost $\left(\mathrm{X}_{3}\right)$ gives a positive and significant direct effect on operational frequency $\left(\mathrm{Y}_{1}\right)$.It means that if there is operational cost increasing (X3) of Rp 1, it will be able to increase operational frequency $\left(\mathrm{Y}_{1}\right)$ of 0.19 times with the assumption that the other factors have a constant value.

Based on these data above, it can be concluded that there is the positive and significant effect among investment, operational experience and operational cost on operational frequency in tuna capture fishery fishermen household in Maluku Province.

\section{b. There is the positive and significant effect among investTerdapat pengaruh positif dan signifikan antarament, operational experience, operational cost, and productivity}

The first, coefisient effect of investment variable $\left(\mathrm{X}_{1}\right)$ on productivity $\left(\mathrm{Y}_{2}\right)$ is 1.526 with critical ratio value of 3.788 and significance level of $0.000<0.05$. These values indicated that there is the positive and significant effect between investment variable investasi $\left(\mathrm{X}_{1}\right)$ and productivity $\left(\mathrm{Y}_{2}\right)$. If there is 1 unit investment increasing $\left(\mathrm{X}_{1}\right)$, it will be able to increase productivity $\left(\mathrm{Y}_{2}\right)$ of $1.526 \mathrm{~kg}$ per trip with the assumption that the other factors have a constant value.

The second, Analysis result exhibits that the effect coefisient of operational experience $\left(\mathrm{X}_{2}\right)$ on Productivity $\left(\mathrm{Y}_{2}\right)$ is 5.228 with critical ratio value of 9.485 and probability error $0.00<0.05$. It means that there is the positive and significant effect between fishing operational experience variable $\left(\mathrm{X}_{2}\right)$ andproductivity $\left(\mathrm{Y}_{2}\right)$. ). If there is 1 unit fishing operational experience increasing it will increase the productivity of $5.228 \mathrm{kgwith}$ the assumption that the other factors have a constant value.

The third, effect coefisient between operational cost $\left(\mathrm{X}_{3}\right)$ and productivity $\left(\mathrm{Y}_{2}\right)$ is 0.020 with critical ratio value of 3.367and probability errorvalue or significance level of $0.000<0.05$. These values give the information that there is the positive and significant effect between operational cost $\left(\mathrm{X}_{3}\right)$ and productivity $\left(\mathrm{Y}_{2}\right)$. If there is 1 unit 
fishing operational experience increasing it will increase the productivity of $0.02 \mathrm{~kg}$ with the assumption that the other factors have a constant value.

Those data explained that there is the positive and significant effect among investment, operational experience and operational cost on productivity of tuna capture fishery fishermen household.

\section{c. There is the positive and significant effect between operational frequency and productivity}

The coefisient effect ofoperational frequency variable $\left(\mathrm{Y}_{1}\right)$ on productivity $\left(\mathrm{Y}_{2}\right)$ is 12.627 with critical ratio value of 8.866and significance level of $0.000<0.05$. These values indicated that there is the positive and significant effect between fishing operational frequency $\left(\mathrm{Y}_{1}\right)$ and productivity $\left(\mathrm{Y}_{2}\right)$. If there is 1 unit operational frequency increasing $\left(\mathrm{Y}_{1}\right)$, it will be able to increase productivity $\left(\mathrm{Y}_{2}\right)$ of $12.63 \%$ with the assumption that the other factors have a constant value.

d.There is the positive and significant effect among investment, operational experience, operational cost, operational revenue

The first, based on result count, it is found that the effect coefisient of investmeny $\left(\mathrm{X}_{1}\right)$ onoperational revenue $\left(\mathrm{Y}_{3}\right)$ is $\mathrm{Rp} 1.087 .743 .924$ with critical ratio value of 12328 andsignificance level of $0.00<0.05$. It means that there is the positive and significant effect between the two variables. If there is Rp.1,- investment $\left(\mathrm{X}_{1}\right)$ increasing it will result the operational revenue increasing $\left(\mathrm{Y}_{3}\right)$ of $\mathrm{Rp}$. 1.087.743.924. In turn, operational revenue will decrease with the similar value if there is investment decreasing.

The second, effect estimation coefisient of operational experience $\left(\mathrm{X}_{2}\right)$ onoperational revenue $\left(\mathrm{Y}_{3}\right)$ is 943240 . This coefisient value indicated that if there is operational experience change $\left(\mathrm{X}_{2}\right)$, it will result in effect on operational revenue change of Rp. 943. 240,- with the assumption that the other factors have a constant value. This coefisient values obtained showed probabilitty error value or significance level of $0.000<0.05$. It showed the presence of positive and significant effect of operational experience $\left(\mathrm{X}_{2}\right)$ onoperational revenue $\left(\mathrm{Y}_{3}\right)$ and indicated that if there is operational experience change, it also will give an effect on operational revenue.

The third, effect coefisient of operational cost $\left(\mathrm{X}_{3}\right)$ onoperational revenue $\left(\mathrm{Y}_{3}\right)$ is 2.647. It means if there is $\mathrm{Rp}$. 1,-operational revenue increasing it will increase operational revenue of Rp. 2647,- with the assumption that the other factors have a constant value. It indicated that operational cost (X3) give a positive and significant effect on operational revenue (Y3) with significance level $0.000<0.05$.

From those explanations, hypothesis about the existence of positive and significant effect of investment, operational experience and operational cost on operational revenue is proved.

\section{e.There is positive and significant effect of operational frequence and productivity onoperational revenue}

The first, effect coefisient of operational frequence and productivity variables is 12.627 with critical ratio value of 8.866 andsignificance level of $0.000<0.05$. It showed that operational frequence (Y1) resulted in a positive and significant effect on productivity variables $\left(\mathrm{Y}_{2}\right)$ in which if there is 1 unit operational frequency increasing, it was able to increase $12.63 \%$ productivity and in turn, with the assumption that the other factors have a constant value.

The second, effect coefisient of operational frequence $(\mathrm{Y} 1)$ on operational revenue $\left(\mathrm{Y}_{3}\right)$ is 114400.607 with significance level of $0.862>0.05$. It means that there is no positive and significant effect of operational frequency $\left(\mathrm{Y}_{1}\right)$ on operational revenue $\left(\mathrm{Y}_{3}\right)$ with the assumption of the other factors value equal constant.

The third, effect coefisient of productivity $\left(\mathrm{Y}_{2}\right)$ on operational revenue $\left(\mathrm{Y}_{3}\right)$ is 14070.555 with probability error of $0.018<0.05$. It indicated that productivity $\left(\mathrm{Y}_{2}\right)$ has positive and significant effect on operational revenue $\left(\mathrm{Y}_{3}\right)$. If there is the occurrence of productivity change $\left(\mathrm{Y}_{2}\right)$, operational revenue also changes with the similar change purpose.

All data above showed that there is positive and significant effect of operational frequency $\left(\mathrm{Y}_{1}\right)$ on25acility25ity $\left(\mathrm{Y}_{2}\right)$, productivity $\left(\mathrm{Y}_{2}\right)$ onoperational revenue $\left(\mathrm{Y}_{3}\right)$. Meanwhile, operational frequency $\left(\mathrm{Y}_{1}\right)$ onoperational revenue $\left(\mathrm{Y}_{3}\right)$ does not show any significance effect eventhough, its effect purpose is positive.

f.There is positive and significant effect of operationl frequence and operational revenue on profitability. 
The first, effectcoefisientof operational frequency $\left(\mathrm{Y}_{1}\right)$ on profitability $\left(\mathrm{Y}_{4}\right)$ is 0.581 with significance level of $0.389>0.05$ and critical ratio value as reflection of calculated $t$ value of 0.861 . These values indicated there is no any significant effect of operational frequency $\left(\mathrm{Y}_{1}\right)$ on profitability $\left(\mathrm{Y}_{4}\right)$.

The second, effect coefisien value of productivity $\left(\mathrm{Y}_{2}\right)$ onprofitability $\left(\mathrm{Y}_{4}\right)$ is 0.23 with significance level of $0.451>0.05$ and cirical ratio value of 0.278 . These values give the information that productivity $\left(\mathrm{Y}_{2}\right)$ does not give any significant effect on profitability $\left(\mathrm{Y}_{4}\right)$ with the assumption that the other factors have a constant value.

The third, effect coefisien value of operational revenue $\left(\mathrm{Y}_{3}\right)$ onprofitability $\left(\mathrm{Y}_{4}\right)$ is 0.20 with significance level of $0.003<0.05$ and critical ratio value of 2.978. It means that there is positive and significant effect of operational revenue $\left(\mathrm{Y}_{3}\right)$ on profitability $\left(\mathrm{Y}_{4}\right)$. It also indicated that if there is Rp. 1,- operational revenue change, it will increase $0.2 \%$ profitability and in turn with the assumption that the other factors have a constant value.

\subsubsection{Indirect Effect}

There is indirect effect of investment $\left(\mathrm{X}_{1}\right)$ on productivity $\left(\mathrm{Y}_{2}\right)$ through operational frequency $\left(\mathrm{Y}_{1}\right)$ with the effect coefisient value of 1.373. This coefisient value is lower than the similar coefisient of direct effect (12.627). These values indicated that direct investment effect on productivity is higher thanits effect which must be through operational frequence.

Indirect effect of investment $\left(\mathrm{X}_{1}\right)$ onoperational revenue $\left(\mathrm{Y}_{3}\right)$ is also detected bynegative coefisient valueof 177662.016. Indirect coefisient value gives the different movement to direct coefisient value for the similar variables. This difference is detected by the presence of positive direct coefisient value of 1087743.924. Seen to direct effect, it can be said that if there is investment increasing, it causes operational revenue increasing. In contrast, indirect effect showed that there is operational revenue decreasing if investmen increases. Indirect effect is also indicated by investment $\left(\mathrm{X}_{1}\right)$ on profitability $\left(\mathrm{Y}_{4}\right)$ with coefisient value of 0.048 . The effect of two similar variables directly is higher (0.581). It means that investment variable $\left(\mathrm{X}_{1}\right)$ gives more influence than its indirect effect.

Operational experience variable $\left(\mathrm{X}_{2}\right)$ has an indirect effect productivity $\left(\mathrm{Y}_{2}\right)$ because it must be through operational frequency variable $\left(\mathrm{Y}_{1}\right)$. Indirect effect coefisient value is 4.816 and lower than direct effect coefisient value(5.228). It proved that direct effect gives more influence than indirect effectof operational experience on productivity.Operational experience variable $\left(\mathrm{X}_{2}\right)$ also indirectly influence on operational revenue variable $\left(\mathrm{Y}_{3}\right)$ through operational experience variable $\left(\mathrm{Y}_{2}\right)$ with effect coefisient value of - 97686.551. Measured to direct effect, operational experience variable $\left(\mathrm{X}_{2}\right)$ hasthe higher influence and positive (94240). Operational experience variable $\left(\mathrm{X}_{2}\right)$ gives indirect effect on profitability $\left(\mathrm{Y}_{4}\right)$ with indirect effect coefisient value of0.390. Indirectly, these two variables have no influence each other and their effect are only obtained if they are indirectly measured.

Operational cost variable $\left(\mathrm{X}_{3}\right)$ has indirect effect onoperational revenue $\left(\mathrm{Y}_{3}\right)$ through operational frequency variable $\left(\mathrm{Y}_{1}\right)$ and productivity $\left(\mathrm{Y}_{2}\right)$. Nevertheless, indirect effect has different purpose withdirect effect.It can be seen at indirect effect coefisient value of $-0,074$ and its direct effect coefisient value of 2.674.Indirect and direct effect gives the similar influence on operational experience variable.

\subsection{Analysis andEffect Implication of Investment, Operational Experience and Operational Cost on Operational Frequency, Productivity,OperationalRevenue, and Profitability of Tuna Capture Fishery Fishermen Household in Moluccas Province}

\subsubsection{Investment Effect, Operational Experience and Operational Cost on Operational Frequence}

Investment results in a positive and significant effect on operational frequency and gives the illustration that investment increasing is able to increase operational frequence.It means that if tuna capture fishery fishermen household increase investment of fishing fleet, it will be able to increase operational frequence of tuna capture fishery fishermen household. Result of this study indicated that fleet addition program by either government or tuna capture fishery fishermen household individually gives an effect on operational frequence increasing.

Positive and significant effect of operational experience on operational frequence results in a positive influence on operational frequence.

If tuna capture fishery fishermen household has no experience, processing of fishfrom catched at hook to fish management process will take a long time causing home back time from fishing operational will also take a long time. It automaticly influences operational frequency.

Operational cost gives positive and significant effect on operational frequency. It means that beside operational experience, operational cost also influences on operational frequency of tuna capture fishery 
fishermen household in its operational activity. Operational cost is dominated by fuel cost which is the big cost in operational activity of tuna capture fishery fishermen household. Therefore, the increasing of operational cost will also increase operational ability and finally increase operational frequency.

This study also exhibits that weather is not inhibitor factor. The inhibition factor to fishing operational activity of tuna capture fishery fishermen household is the lack of costfor supplying of the minimum need such as fuel, oil and ice. If fishing operational cost need is fulfilled, tuna capture fishery fishermen household can operate 6 times a week.

Implication obtained contradicst to hypothesis explanation that fishing operational activity of tuna capture fishery fishermen household still can be increase if there is investment increasing, continuity of cost supplying and fishing operational experience.

\subsubsection{Effect of Investment, Operational Frequency and Operational Cost on Productivity}

Investment gives a positive effect on productivity meaning that fleet addition will result in investment increasing causing the ability of fleet to do fishing activity increases, and finally increase productivity. Investment oftuna fishing fleet still has oppurtinity to be developed because fleet development will increase production of tuna capture fishery fishermen household.

Positive effect of operational cost on productivity supported the field situation that if there is the increasing of operational cost, it will increase the ability for fishing operational with a longer distanct which can result in the more catch.If there is operational cost addition to increasethe ability of reach and fishing operational time. The increasing ability of reach and fishing operational time influences on the increasing of fishing number per trip or per week.

The result of this study showed that tuna capture fishery in Moluccas Province is still under-exploited indicated by the operational cost presence which gives a positive effect on productivity. This fact is unusual in fishing operational activities in the other regions in which the operational cost presence results in a negative effect on productivity.

Automaticly, government policy 27acilit on implementation of Rural Mina Business (RMBP) Program is very precise. The development of RMBP is done by expansion of tuna capture fishery fishermen and coordinated through Collective Business Group (CBG) to get development aid facility.

Implication of this study result on the second hypothesis testing is that productivity can be increased through the development of investment which can increase operational frequency as indicator of effective productivity level or effective cath level.

\subsubsection{Effect of Operational Frequency on Productivity}

Positive and significant coefisient of operational frequency on productivity shows that operational frequency gives a positive effect on productivity. It give an information that the more of operational frequency the more of cath number per week. This situation will influence productivity of tuna capture fishery fishermen household. It also explains that 1 fisherman will results in net fish catch range 40-60 kg/trip which are ready for being sold to collector.

Implication of hypothesis testing is that productivity or effective catch level can be increased if operational frequency can also be increased.

\subsubsection{Pengaruh Investasi, Pengalaman Melaut Dan Biaya Melaut Terhadap Pendapatan Operasi.}

Positive and significant effect of investment on operational revenue exhibits that investment give a positive effect on operational revenue. It indicats that there is opportunity to develop tuna capture fishery in Moluccas province through the increasing of fleet.

Implementation policy of RMBP as tuna capture fishery fishermen household development form has the similar purpose to the achievement of this study result. Therefore, this study supports the implementation RMBP organized by Regency Government Service of Moluccas Province. The development of tuna capture fishery fishermen household need to focus on the implementation of aid distribution to under-exploited Regency/City Region. It can answer the effort to prosper the life of tuna capture fishery fishermen household like its activity condition in Regency/City each.

The field study shows that a big part of tuna capture fishery fishermen household samples had operational experience of 5-10 years and only 37 tuna capture fishery fishermen household had operational experience of $<5$ years.It clearly indicates that the more experience the more opportunity gets the higher catch which finally increases operational revenue.

Based on the cost composition, the cost of fuel is the highest cost component of operational cost components. It gives information that operational cost is dominated by fuel cost. The operational cost very influence operational revenue of tuna capture fishery fishermen household. The various price of fuel is depended on location price each. 
The movement condition of operational cost having the similar purpose to operational revenue can not be separated with under-exploited area determining as the area of this study. It is similar to the theoryconcept of Waridin, (2005) using Schaeffer model with some modifications that every operational cost change of under-exploited area is still lower than its fish catch/ catch value[16]. As well known that operational cost change reflects Maksimum Sustainablity Effort (MSE) and fish catch/ catch valuereflects Maksimum Sustainiblity Yield (MSY) atau MSE < MSY. Therefore, it can be said that every operational cost changewill results in the higher revenue change.

Operational revenue oftuna capture fishery fishermen household will be very influenced by investment, operational frequency and operationl cost.

\subsubsection{Effect of Operational Frequency and Productivity on Operational Revenue}

Effect of operational frequency on operational revenue is positive and significant. This effect shows that if there is productivity increasing, it will influence on operational revenue increasing as much as its estimation coefisient. The high productivity reflects the high catch average of tuna capture fishery fishermen household per certain period (per week). If catch average per trip per week is high, it will automaticly increase operational revenue.

Based on Maksimum Sustainiblity Yield (MSY) which is still under-exploited inFisheries Management Region (FMR) of around Seram and Banda Ocean, the increasing of exploitation through fleet development still might be done. The development using fleet concept with operational of tuna capture fishery fishermen household which has cluster base can give the opportunity for the occurency of tuna capture fishery fishermen household operational revenue increasing.

Implication of hypothesis result testing is that the more productive of tuna capture fishery fishermen household the more increasing of operational revenue is.

\subsubsection{Effect of Operational Frequence, ProductivityandOperational Cost onProfitability}

Effect of operational frequency on profitability based on calculation result is not significant eventhough it has a positive effect purpose. The change of operational frequency gives indefinite effect on profitability of tuna capture fishery fishermen household.

It supported the fact that operational frequence directly influences on profitability butoperational frequence is only a mediator element relatinginvestment andoperational experience to profitability. The change of operational frequence has opportunity to increaseproductivity finally, increase operational revenue.

Produktivity variable shows a positive but insignificant effect on provitability.It gives the information that if there is the increasing of productivity, it will influence profitability but it must be through operational revenue.

Positive and significant influence of operational revenue variable on profitability variable exhibits that if there is 1 unit of operational revenue increasing, it will influence profitability of $2 \%$. This effect is total influence of all variables either moderation variable such asoperational frequence and profitability or exogen variablesuch as investment, operational experience and operational cost.

Overall, this study analysis shows that investment, operational experience and operational costwere able to direclt influence on profitability and also can give an effect on profitability through moderation variablesuch as operational frequence and provitability.

Implication of this study is investment, fishing operational frequence and operational cost can be used to influence direct profitability and the similar variableis able to influence profitability through operational frequence variable and poduktivity of tuna capture fishery fishermen household and operational revenue.

\subsection{Conclussion}

\section{Conclussion And Suggestion}

Based on analysis result and analysis result discussion about tuna capture fishery fishermen household profitability in Moluccas Province, it can be concluded as followed:

1. Investment, operational experience and operational cost have direct, positive and significant effect on operational frequence and productivity. It indicated that the change of investment, operational experience and operational cost will be followed bythe change ofoperational frequence and productivity.

2. Fishing operational frequence results in direct, positive and significant effect on provitability.It indicated that if operational frequence is increased, it will increase productivity and in turn, if there is operational frequence decreasing, it will automaticly decrease productivity.

3. Investment, operational experience and operational cost direcly, positively and significantly influence operational revenue. It means that if there is investment increasingand operational cost increasing, it willalso increase operational revenue of tuna capture fishery fishermen householdin Moluccas Propince. 
4. Fishing operational frequence through productivity give a positive and significant effect on operational revenue. Operational revenuehas direct, positive and significant effect on profitability oftuna capture fishery fishermen household. Mean while, operational frequence results in profitability through productivity,finally increase operational followed by profitabilityincreasing.

\subsection{Suggestion}

To develop tuna capture fishery fishermen household, it is suggested as followed:

1. Profitability oftuna capture fishery fishermen household can be increase by the increasing offishing operational frequence, productivity and operational revenue supported by investment development, operational experience increasing and operational cost.

2. To increase function of fisheries sector in under-ekspoited fishery management region which the big potential to be developed, Regency Government Service is hoped to makespecial policyabout: the supplying of fuel facility and icein home-base) and credit facility to fulfillcost need and fleet rehabilitation.

3. To increase the profitability, businessmen need to get knowledge about financial management particularly calculation and determination of fishing operational cost consisted of variable cost and permanent cost.

\section{Acknowledgement}

The Authors thanked to Prof. Dr.Karim Saleh, Prof. Dr. N. Brasit and all friends for their helping to finish this study.

\section{Reference}

[1] Fisheries and Marine Departement of Maluku, AnnualReport of Fisheries and Marine Departement of Maluku, 2007.

[2] Widodo, J.,dan Suadi.Pengelolaan Sumber Daya Perikanan Laut, ( Cetakan Kedua, Yogyakarta, Penerbit Gadjah Mada University Press, 2008),

[3] Wiadnya, -D.G.R, R. Djohani, M.V. Erdmann, A. Halim, M. Knight, Peter J. Mous and L. Pet-Soede. Study of Capture FisheryManagement Police Kebijakan in Indonesia: Giong to Marine Protection Region Forming. The Nature Conservacy Southeast Asia Center for Marine Protected Areas, Bali Indonesia, 2009.

[4] Fauzi, A.. Fisheries and Marine Policy, Issue, Synthesis and Idea, PT Gramedia Pustaka Utama Publisher, Jakarta, 2005.

[5] Saefudin, A. M.,and A.M. HanafiahTata Niaga Hasil Perikanan, Second Publication, Universitas Indonesia Publisher, Jakarta, 2006.

[6] Nikijuluw, V. P. H., Abrahamz, J. and Dangeubun F.D.W.Study of FisheriesandMarine Base Data of Moluccas for the sustainable Investment,Published byFisheriesand marine Service of Moluccas Propince, 2007

[7] Fisheries and Marine Service of Muluccas, 2007. Statistic for Fisheries in Maluku Province, 2007

[8] Hilborn, R. and C. J. Walters. 1992. Quantitative Fisheries Stock Assessment : Choice,Dynamics and Uncertainty. Chapman and Hall, New York, 1992.

[9] Pascoe, S. and S. Mardle. Optimal Fleet Size in the English Chanel : A MultiObjective Programming Approach.European Review of AgriculturalEconomics, 28 (2).2001, 161-185.

[10] Bergevin, P. M.Financial Statement Analysis, An Integreted Approach. Prentice Hall, Pearson Education International, Inc.Upper Saddle River, New Jersey, 2002.

[11] Papilaya, Evaluasi Usaha Perikanan Tangkap Huhate di Kecamatan Saparua. Ichthyos,.3( 2), Juli 2004; 65-70. http://katalog.pdii.lipi.go.id

[12] Clark, C.W., R.M. Gordon and T.C. Anthony.Fisheries, Dynamics and Uncertainty : Progress in Natural Resources Economics. Clarendon Press, Oxford.1985.

[13] Mehmet, B.,and V. Ceyhan. Cost and Profitability for Trout and Sea Bass Production in the Black Sea, Turkey, Journal of Animal and Veterinary Advance, Medwell Publishing.2009.

[14] Indriantoro, N., andSupomo B. Method ofBusiness Study for Accountancy and Management, Publisher of Ecomoni Faculty, University of Gadjah Mada, First Edition, Second publication, Yogyakarta.2002

[15] Babbie, E.The Practice of Social Research, Wadsworth Publishing. Co., Belmont, California,1983.

[16] Waridin.Eficiency Analysis of Cantrang Capture Toolin Pemalang, Central Java. ejournal Universitas Diponegoro, Semarang. 2005http://ejournal.unud.ac.id/ Abstract/(8)soca-waridin-efisiensi 